\title{
3D inversion of the Sichuan Basin magnetic anomaly in South China and its geological significance
}

\author{
Jie Wang ${ }^{1,2,3}$, Changli Yao ${ }^{2 *}$, Zelin Li ${ }^{4}$, Yuanman Zheng ${ }^{2}$, Xuhui Shen ${ }^{1}$, Zhima Zeren ${ }^{1}$ and Wenlong Liu ${ }^{3}$
}

\begin{abstract}
The Sichuan Basin magnetic anomaly is the most striking regional aeromagnetic anomaly in South China. It is characterized by a continuous large-scale linear magnetic anomaly and contains long-wavelength constituents which could still be detected on satellites. However, Sichuan Basin is covered by 4 to $10 \mathrm{~km}$ thick non-magnetic sedimentary layers from Neoproterozoic to Cenozoic, which conceals the magnetic sources in the Precambrian basement and makes it difficult to explore the geological origin of the Sichuan Basin magnetic anomaly. In this study, we applied 3D inversion to the magnetic data, and then compared our inverted susceptibility model with geological maps. We found that the spatial distribution of the Sichuan Basin magnetic anomaly controls the range of the rigid basement beneath Sichuan Basin and it is surrounded by the widespread Neoproterozoic magmatic complexes. Based on our analysis, we proposed that the geological origin of the Sichuan Basin magnetic anomaly might be related to the craton-scale Neoproterozoic magmatic event, which has played an important role in the stabilization of the basement and the evolution of the deep crust in Sichuan Basin.
\end{abstract}

Keywords: Magnetic anomaly, Long-wavelength magnetic anomaly, 3D inversion, Sichuan Basin, South China, Neoproterozoic

\section{Introduction}

There is a large linear aeromagnetic anomaly in Sichuan Basin, South China, extending continuously more than $1000 \mathrm{~km}$ with a broad width of ca. $100 \mathrm{~km}$. Sichuan Basin magnetic anomaly contains long-wavelength signals which decay slowly with distance and could be detected on satellites. The sources for long-wavelength magnetic anomalies are generally interpreted as large-scale maficultramafic rocks with strong magnetization in the midlower crust, e.g., the Bangui magnetic anomaly in Central African Republic (Regan and Marsh 1982), Mackenzie River magnetic anomaly in western Canada (Pilkington and Saltus 2009) and the magnetic anomaly of the North American Midcontinent Rift system (Hinze et al. 1992).

\footnotetext{
*Correspondence: clyao@cugb.edu.cn

${ }^{2}$ School of Geophysics and Information, China University of Geosciences, Beijing, China

Full list of author information is available at the end of the article
}

Sichuan Basin is covered by non-magnetic 4 to $10 \mathrm{~km}$ thick sedimentary layers, and the magnetic source is not exposed on surface, so the strongly magnetized rocks for the magnetic anomaly should be in the Precambrian basement of Sichuan Basin. Sichuan Basin magnetic anomaly reveals the magnetization difference of the basement, and it has attracted the interests of many researchers to study its origin (Zhang et al. 1995; Luo 1998; Gu and Wang 2014; Xiong et al. 2015). Some researchers thought it might reflect the strongly magnetized intrusions beneath the basin (Luo 1998; Guo et al. 2016); however, there is no direct proof to determine its geological origin. There are no drilling data on the magnetic anomaly to figure out the properties of these strongly magnetized rocks. The geological origin of the Sichuan Basin magnetic anomaly is still not clear.

Regional magnetic anomalies could reflect the deep structure of the buried basement. They are always formed by large-scale magmatic activities and related 
to significant tectonic events in geological history. Therefore, the formation of the Sichuan Basin magnetic anomaly should be related to important Precambrian geological events and influence the crustal evolution of the basement. In this work, we studied the Sichuan Basin magnetic anomaly by 3D inversion; then we discussed our inversion results with other geodata and further analyze its geological significance.

\section{Geological settings}

Sichuan Basin is in the Yangtze Terrane of the South China Craton, which constitutes the Yangtze Terrane in the northwest and the Cathaysia Terrane in the southeast (Fig. 1). The basement of Sichuan Basin is formed in Precambrian period and covered by 4 to $10 \mathrm{~km}$ thick layered sedimentary successions from late Neoproterozoic to Cenozoic (Dong et al. 2013; Gao et al. 2016).

During Precambrian Period, there are multi-stage magmatic activities and tectono-thermal events happened in the Yangtze Terrane, recording the formation of the antient continent-nucleus, cratonization, crustal remelting and growth (Zheng and Zhang 2007). The Archean Kongling complex lies near Yichang in the eastern part of Sichuan Basin, which is the oldest basement exposed in Yangtze Terrane and represents the initial formation of the continent-nucleus of the Yangtze Terrane (Zheng et al. 2006; Gao et al. 2011). The zircon data of the Kongling complex also reflect the crustal reworking in Paleoproterozoic and the formation of the uppermost crust of the Yangtze Terrane (Zheng et al. 2006). On surface, the outcrops of the Archean and Paleoproterozoic rocks are very limited in spatial distribution. There are widespread Neoproterozoic magmatic rocks exposed in the periphery of the Yangtze Terrane, which indicates that the Yangtze Terrane had experienced extensive remelting and formed massive juvenile crust during Neoproterozoic, the same period as the formation and break-up of the supercontinent Rodinia, generating a lot of magmatic intrusions and volcanic eruptions around the Yangtze Terrane (Li et al. 2003a, 2003b, 2008; Zheng et al. 2007; Wang et al. 2009, 2010).

From the late Neoproterozoic, the Sichuan Basin becomes a stabilized cratonic basin and acts as a rigid block resisting subsequent tectonic compressions. The sedimentary layers inside Sichuan Basin are lessdeformed and kept sub-horizontal, but the crust surrounding the Sichuan Basin has gone through intense deformation from Mesozoic to Cenozoic: in the northern margin of the Sichuan Basin, the Dabashan thrust fault belt was formed during the $\mathrm{N}-\mathrm{S}$ convergence between the North and South China Craton in Jurrasic (Dong et al. 2013); the westward subduction of the Paleo-Pacific plate beneath the South China caused the broad thrustfold belt in eastern Sichuan Basin (Zhang et al. 2011); the eastward extrusion of Songpan-Ganzi Terrane of Himalayan-Tibetan plateau reactivated the Longmenshan thrust fault belt in the western margin of Sichuan Basin, and

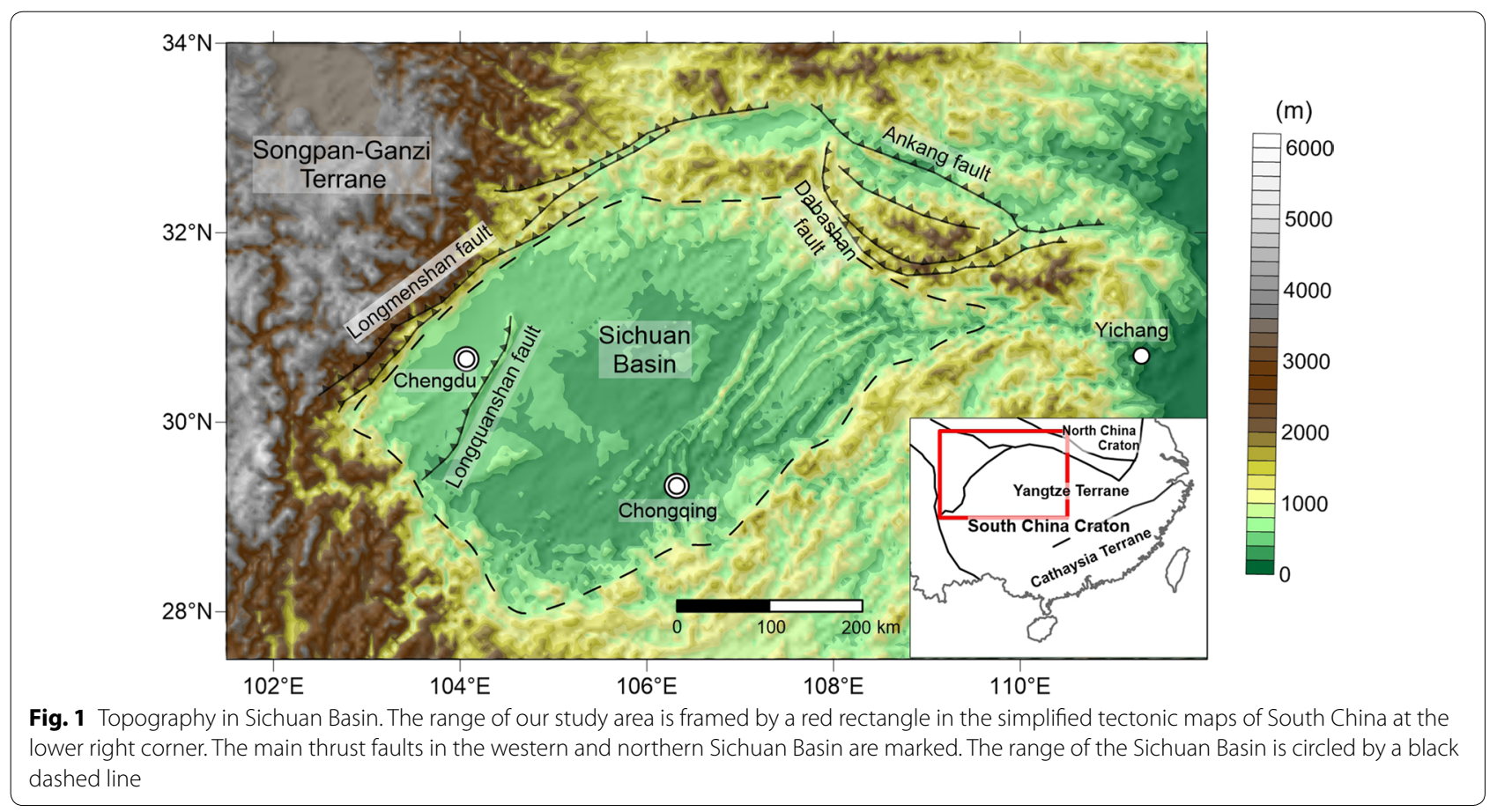


the famous Longmenshan fault is still active and causes earthquakes until now (Zhang et al. 2009).

\section{Magnetic anomaly data}

Figure 2a is the total-field magnetic anomaly in Sichuan Basin with a spatial resolution of $2 \operatorname{arc}(\approx 3.5 \mathrm{~km})$ at $4 \mathrm{~km}$ altitude. The Sichuan Basin magnetic anomaly is the largest one in South China, which is a wide linear magnetic anomaly extending continuously more than $1000 \mathrm{~km}$ with a main NE trending in the western to middle part and SE trending in the easternmost part. The highest value of the magnetic anomaly reaches $360 \mathrm{nT}$. The magnetic high anomaly has a broad width of ca. $100 \mathrm{~km}$ and changes slowly. The obvious magnetic low is almost parallel to the magnetic high on the north with the lowest value -240 nT, which is mostly a manifestation of oblique magnetization. The magnetic data are collected in EMAG2 (Earth Magnetic Anomaly Grid, 2 arc-minute resolution, https ://www.ngdc.noaa.gov/geomag/emag2.html), which is compiled from satellite, airborne and marine magnetic data. The magnetic anomaly in Fig. 2a mainly reflects the short-medium wavelength signals acquired by aeromagnetic surveys.
Reduction to the pole (RTP) is to reduce the influences of oblique magnetization. In oblique magnetization, the locations of magnetic anomalies would shift laterally over the sources and the shape of magnetic anomalies would be skewed (Blakely 1995). In our study area, the inclination of geomagnetic field is ca. $48^{\circ}$ and the declination is ca. $0^{\circ}$, i.e., the magnetic anomalies are caused by oblique magnetization. It is noted that if we would like to compare magnetic anomalies with geological maps or other geodata, RTP is necessary so that the magnetic anomalies can better reflect their source locations. Compared to Fig. 2a, the location of the RTP magnetic anomaly in Fig. $2 \mathrm{~b}$ migrates northward ca. $50 \mathrm{~km}$. The magnetic low accompanying the magnetic high on the north decreases a lot and the shape of the magnetic high becomes more symmetrical.

Figure $2 \mathrm{c}$ is the total-field long-wavelength magnetic anomaly in Sichuan Basin, obtained by satellite magnetic surveys. The data in Fig. $2 \mathrm{c}$ are extracted from the MF7 model (http://geomag.colorado.edu/magnetic-field -model-mf7.html), which is produced using CHAMP satellite measurements and compiled at WGS84 ellipsoid altitude (close to the Earth's surface). At hundreds of kilometers height of satellites, the short-medium wavelength
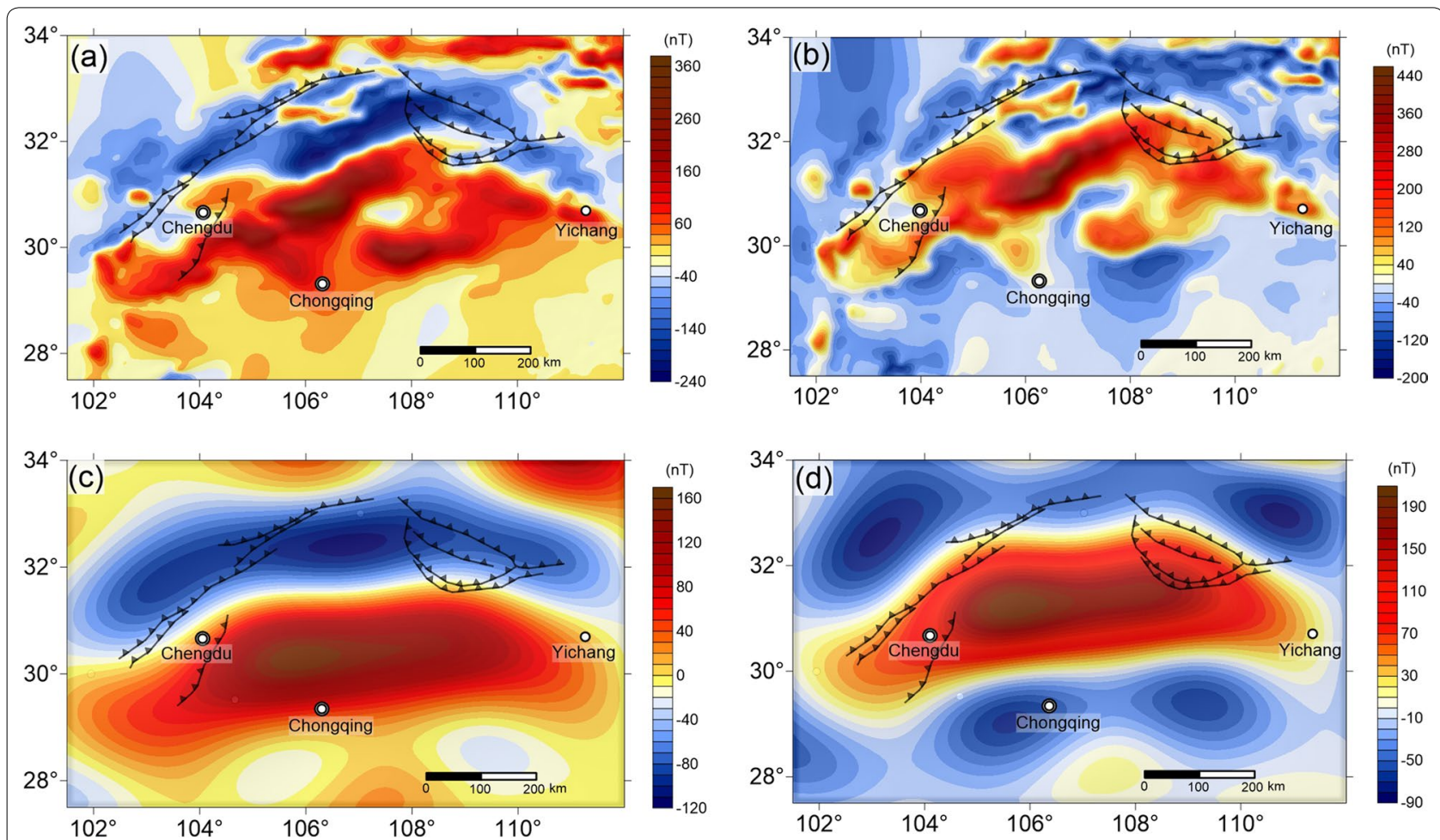

Fig. 2 Magnetic anomaly in Sichuan Basin. a Total-field aeromagnetic anomaly at $4 \mathrm{~km}$ altitude. b RTP (reduction-to-the-pole) aeromagnetic anomaly at $4 \mathrm{~km}$ altitude. c Total-field long-wavelength magnetic anomaly. The data are from the MF7 model using CHAMP satellite measurements and compiled at WGS-84 ellipsoid altitude. It could be downloaded from the website http://geomag.colorado.edu/magnetic-field-model-mf7.html. d RTP long-wavelength magnetic anomaly. The main thrust faults have been overlaid to each magnetic anomaly 
magnetic anomalies have mostly attenuated, only the long-wavelength parts still exist and could be detected by the magnetometer on satellites. Figure $2 \mathrm{~d}$ is the magnetic anomaly in Fig. 2c after RTP. The trending and spatial scopes of the long-wavelength magnetic anomaly in Fig. 2c, d are consistent with those of the aeromagnetic anomaly in Fig. 2a, b.

\section{Method and results}

To study the deep structure of the magnetic sources, we converted the magnetic anomaly grid data into a sub-surface susceptibility model. For regional magnetic anomalies, Curie depth should be considered as the bottom of the magnetic sources. In this study, we used 3D inversion to the magnetic data constrained by the Curie depth as the source bottom.

\section{Method}

In this study, we adopt 3D inversion of the magnetic data proposed by Li and Oldenburg (1996), which has been widely used in ore-related geophysical exploration to create quantitative models of magnetic sources (Oldenburg et al. 1997; Roy and Clowes 2000; Silva et al. 2001; Fullagar et al. 2004; Aitken and Betts 2009; Lü et al. 2013).

This inversion method assumes that the magnetic anomaly is caused by induced magnetization only. The sub-surface space is discretized into many rectangular cells with unknown susceptibilities. The inversion problem is formulated as an optimization problem. This method minimizes a tradeoff between data misfit and a model norm subject to a positivity constraint. The objective function of this method is

$$
\begin{array}{r}
\min \left\|\mathbf{W}_{d}(\mathbf{d}-\mathbf{G m})\right\|_{2}^{2}+\mu\left\|\mathbf{W}_{m} \mathbf{Z} \mathbf{m}\right\|_{2}^{2} \\
\text { subject to } \quad \mathbf{m} \geq \mathbf{0},
\end{array}
$$

where $\mu$ is a regularization parameter, $\mathbf{d}$ the observed data, $\mathbf{m}$ the model, $\mathbf{G}$ the sensitivity matrix, $\mathbf{W}_{d}$ a diagonal data weighting matrix whose diagonal elements are reciprocals of estimated noise standard deviations, and $\mathbf{W}_{m}$ a model weighting matrix that consists of a weighted sum of zeroth and first-order finite difference matrixes. $\mathbf{Z}$ is a diagonal depth weighting matrix used to avoid recovered models concentrating in the shallow surface. Its $j$ th diagonal element is $z_{j}^{-\beta / 2}$, where $z_{j}$ represents the depth of the $j$ th cell. $\beta$ is a parameter related to the decay rate of the magnetic field. It is generally set to three in 3D inversion to mimic the decay rate of magnetic data produced by a cell at depth. The positivity constraint can not only produce a physically meaningful model because most rocks have positive susceptibilities, but also reduce the redundant structures in the recovered models. For more mathematical details about this method, please refer to $\mathrm{Li}$ and Oldenburg (1996).

\section{The bottom boundary of magnetic sources in Sichuan Basin}

For regional magnetic anomalies, we should use the Curie depths to constrain the bottom boundary of magnetic sources. Crustal temperature increases with depth, when the temperature exceeds Curie points of ferromagnetic minerals, mainly magnetite in crust, these ferromagnetic minerals turn to be paramagnetic and their host rocks could no longer generate magnetic anomalies. The Curie temperature of magnetite in crust is $580{ }^{\circ} \mathrm{C}$; therefore, the isotherm of $580^{\circ} \mathrm{C}$ is considered as the bottom of magnetic sources.

Wang et al. (2000) estimated the crustal geothermal structure in Sichuan Basin by calculating the deep heat flow and using the one-dimensional heat conducting equation, and the estimated Curie depth in Sichuan Basin is $30-50 \mathrm{~km}$. An and Shi (2007) calculated 3D thermal structure beneath China; they adopted surface temperature from ground stations and upper mantle temperature estimated from $\mathrm{S}$-wave velocities as the top and bottom boundary conditions, and the Curie depth of the Sichuan Basin in their results is ca. $40 \mathrm{~km}$. Xiong et al. (2016a) estimated the Curie depth of the Chinese continent using the latest compiled aeromagnetic data by power spectral method; the Curie depth in Sichuan Basin is $30-40 \mathrm{~km}$. Hou (1989) also used aeromagnetic anomalies to estimate the Curie depth in Sichuan Basin, which is $36-50 \mathrm{~km}$. The estimated Curie depth in Sichuan Basin is in the range of $30-50 \mathrm{~km}$ deep, which is around the Moho in Sichuan Basin, 42-50 km, in deep-reflection seismic profiles (Dong et al. 2013; Gao et al. 2016). The real Curie depth should be an uneven surface, but we do not have enough geothermal data to constrain the Curie depth at every place. To simplify the calculation, we just chose a constant value to represent the Curie depth. In our work, to study the properties and distribution of the magnetic sources in Sichuan Basin, especially for the long-wavelength magnetic anomaly, of which the sources are always large or deep, we took $45 \mathrm{~km}$ (almost the deepest estimated Curie depth around the Moho) as the Curie depth to constrain the bottom boundary in $3 \mathrm{D}$ inversion.

\section{Inversion results}

First, it should be assessed that the data in our study area meets the assumption of the method: the magnetic anomaly is dominated by induced magnetization. After RTP, the magnetic low of the Sichuan Basin magnetic anomaly almost disappears and the magnetic high becomes more symmetrical, both implying the direction of the source magnetization is mainly the same as that 
of the present-day geomagnetic field. If strong remanent magnetization exists with a direction not parallel to the present-day geomagnetic field, the RTP of the magnetic anomaly would not give out these improvements in the shape of anomaly. Thus, the Sichuan Basin magnetic anomaly is likely to be dominated by induced magnetization or at least the source magnetization has the same direction as the present-day geomagnetic field. Since there is no rock sample from the magnetic source of the Sichuan Basin magnetic anomaly, it is difficult to determine whether this magnetic anomaly is caused by induced or remanent magnetization. If there exists remanent magnetization with the same direction as the present-day geomagnetic field, then the susceptibility in the inversion results should be considered as equivalent susceptibility, not the real susceptibility, but this would not influence the inversion results.

In our study, the subsurface space was divided into $420 \times 260 \times 18$ cells with side lengths of 1.5 arc-minute $(\approx 2.5 \mathrm{~km})$. During inversion, the source depth is constrained by the Curie depth $45 \mathrm{~km}$ around the Moho, so we set the susceptibilityas zero below the Curie depth. After inversion, we got the sub-surface susceptibility distribution model to $45 \mathrm{~km}$ deep. Figure $3 \mathrm{a}$ is the observed total-field magnetic anomaly in Sichuan Basin. Figure 3c is the calculated magnetic anomaly by our inverted model with a misfit of $1.97 \mathrm{nT}$; the misfit is the root mean square of the difference between the observed data in Fig. 3a and the calculated data in Fig. 3c, and its distribution is shown in Fig. 3d. To reduce the calculation time, we used the observed data after adaptive down-sampling to conduct 3D inversion. The locations of the data points after down-sampling are overlaid on the observed data with black dots, as shown in Fig. 3b.

The inversion results are shown by horizontal slices at different depths $-15 \mathrm{~km}, 25 \mathrm{~km}, 35 \mathrm{~km}$ and $45 \mathrm{~km}$, as shown in Fig. $4 \mathrm{a}-\mathrm{d}$. Figure $5 \mathrm{a}$ displays the results by an iso-surface with a high susceptibility value of $0.03 \mathrm{SI}$. Figure $5 \mathrm{~b}-\mathrm{d}$ shows three vertical slices across the magnetic sources in NW-SE direction, perpendicular to the main trending of the magnetic anomaly, and their locations are shown in Fig. 5a by red dashed lines.

\section{Discussion}

Uncertainty of the inversion results

The main source for the uncertainty of the inversion of magnetic data is the non-uniqueness of potential data, which means that there are infinite mathematic

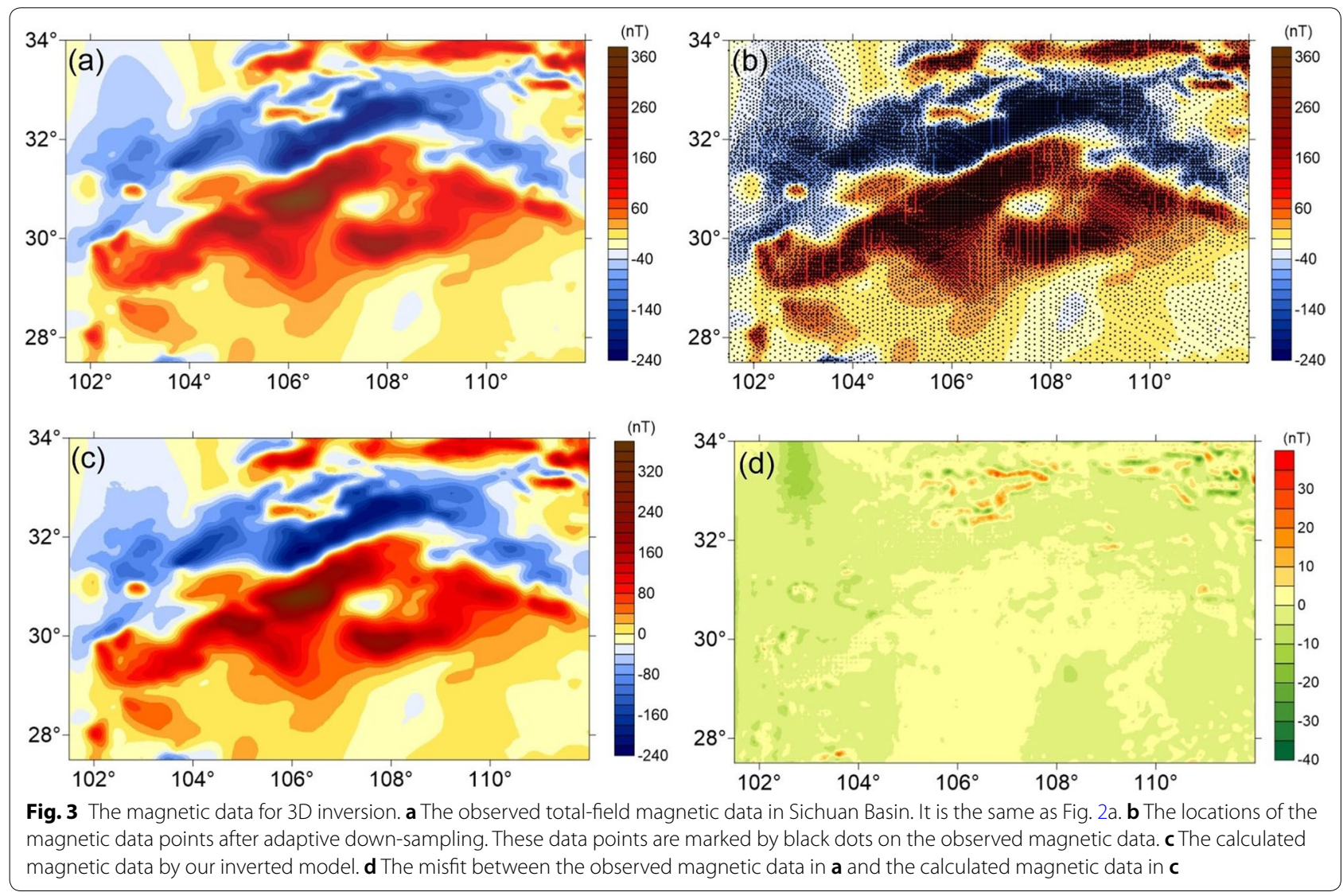



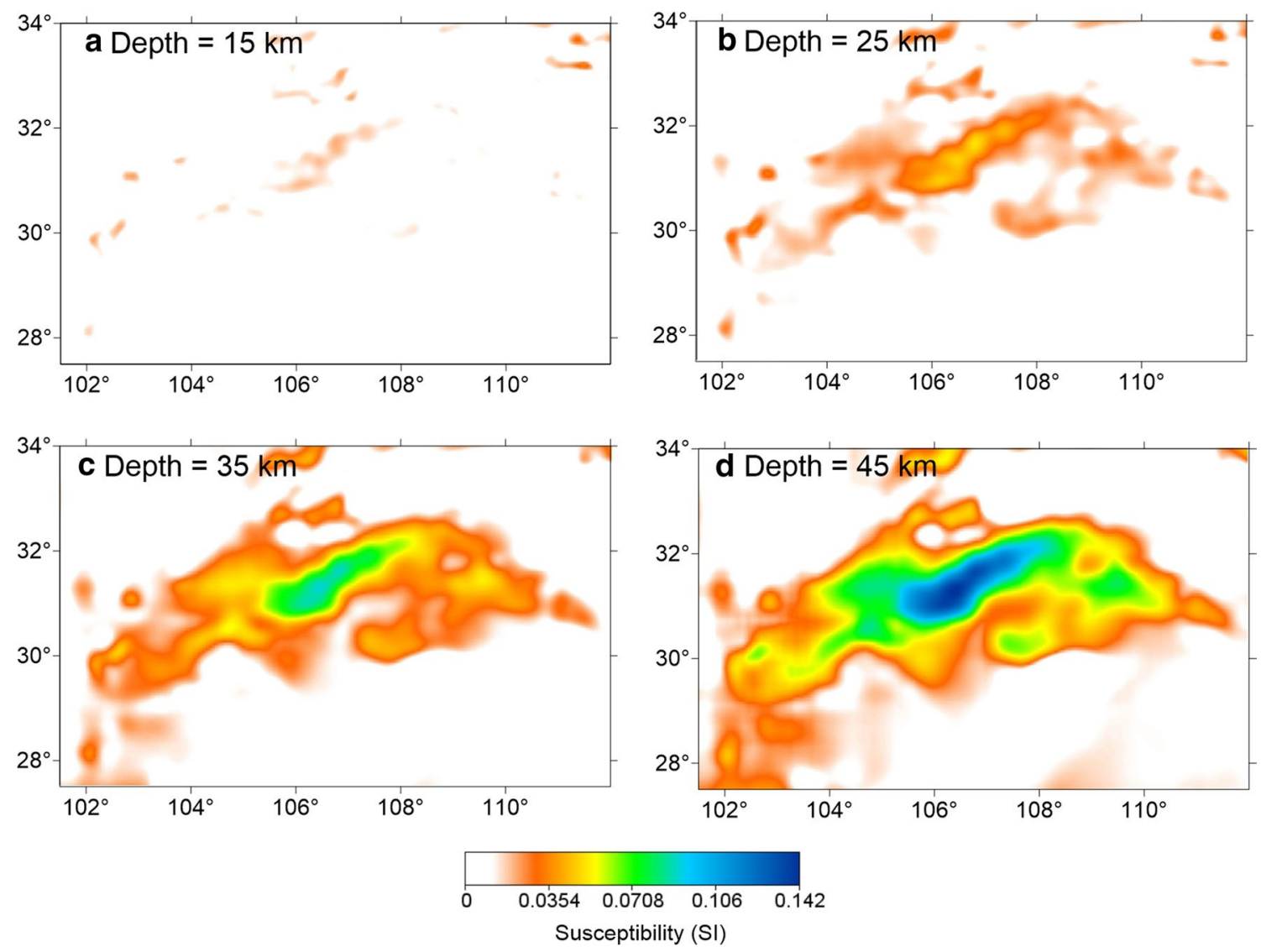

Fig. 4 Horizontal slices of the inverted susceptibility model at different depths. a The slice at depth $=15 \mathrm{~km}$. b The slice at depth $=25 \mathrm{~km}$. c The slice at depth $=35 \mathrm{~km}$. $\mathbf{d}$ The slice at depth $=45 \mathrm{~km}$

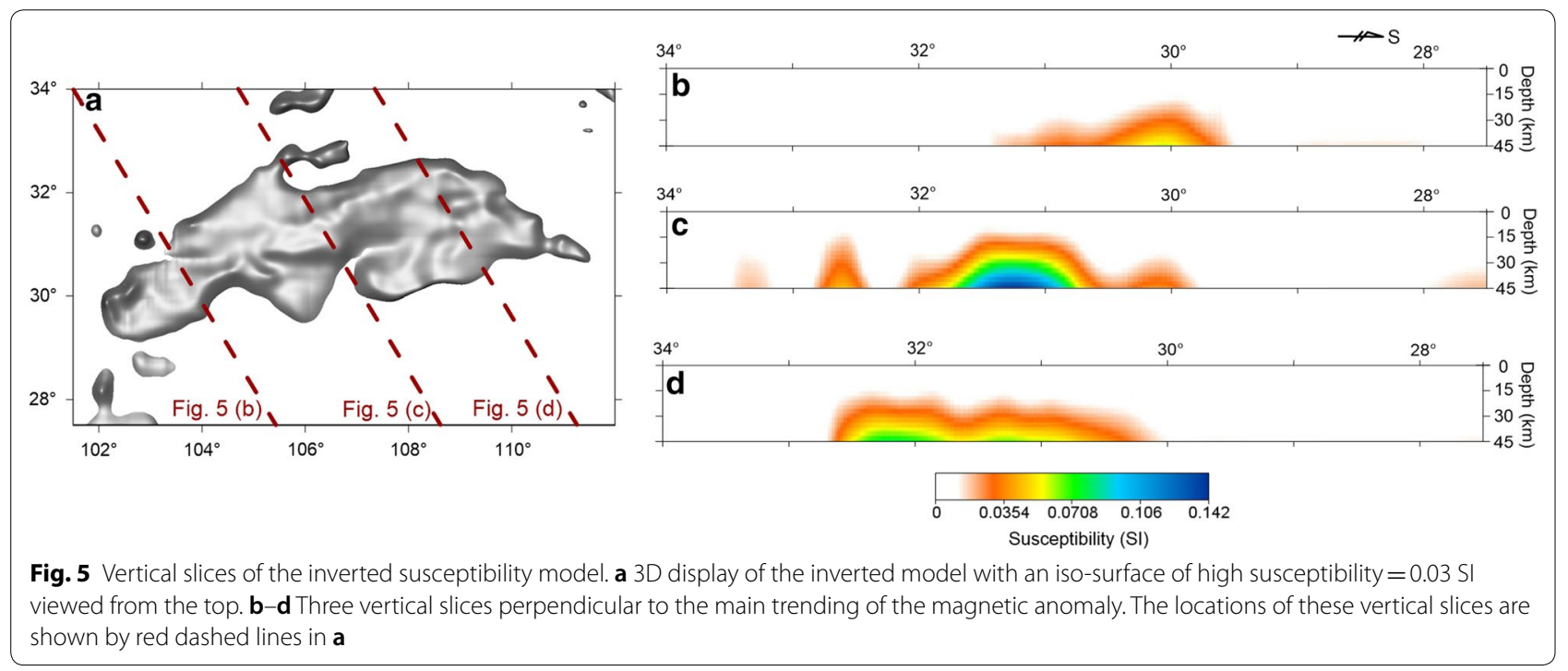

solutions for one set of magnetic data measured on a surface. Magnetic anomaly is affected jointly by the source scale, shape, depth and magnetization. In 3D inversion of magnetic data, the inverted parameters, such as the depth and susceptibility of magnetic sources, are coupled. If we would like to determine one parameter 
reliably, accurate constraints on the other parameters are needed. For large-scale regional magnetic anomalies, the rock magnetization data are often insufficient, because we cannot directly measure the magnetization of inaccessible deep crustal rocks. In addition, it is possible that for a large magnetic body extending tens of kilometers deep, the source rocks have non-uniform magnetization, which makes the case more complicated. Hence, it is difficult to get enough information to constrain the parameters of entire magnetic sources, and the uncertainty of the inversion results is inherent.

In our study, the magnetic sources in Sichuan Basin are deep-seated in its basement, but we do not have any rock magnetization data of the magnetic sources until now. The real Curie surface should be an uneven one, but the estimated Curie depths have a great uncertainty by different methods, so during inversion, we just used a constant Curie depth $45 \mathrm{~km}$ to constrain the bottom boundary of the magnetic sources. Thus, the inverted source depths do not represent the absolute source depths, and our inverted susceptibility model is just a solution under the certain constraints, but the inverted model is very helpful to analyze the magnetic source quantitatively.

\section{Rock magnetization}

In our inverted model, the susceptibilities of the magnetic sources in Sichuan Basin is approximately in the range of 0.03-0.142 SI, equivalent to the magnetization 1.2-5.68 $\mathrm{A} / \mathrm{m}$, reflecting massive strongly magnetized rocks in the deep crust of Sichuan Basin. However, the Sichuan Basin is covered by 4 to $10 \mathrm{~km}$ thick sedimentary layers, which could be considered as non-magnetic, so there are no strongly magnetized rocks exposed at the corresponding places of the magnetic anomaly in Sichuan Basin. There are no drilling data on the high magnetic anomaly in Sichuan Basin, so we could not directly verify the reasonability of the rock magnetization in our inverted model.

Sichuan Basin magnetic anomaly contains long-wavelength constituents, which decay slowly with distance and have deep-seated magnetic sources. For long-wavelength magnetic anomalies, their sources are always interpreted as strongly magnetized rocks in mid-lower crust and even the uppermost mantle (Wasilewski and Mayhew 1982; Brown et al. 2014; Ferré et al. 2014; Friedman et al. 2014; McEnroe et al. 2018). Based on the modeling for the long-wavelength magnetic anomalies and rock magnetism, Mayhew et al. (1985) proposed that the magnetization of the magnetic sources is commonly $2-6 \mathrm{~A} / \mathrm{m}$. Li (2014) studied the rock magnetism of the exposed rocks and xenoliths of the lower crust in North China Craton, among which the mafic granulite has the strongest induced magnetization $2.82 \mathrm{~A} / \mathrm{m}$. Xiong et al. (2016b) published the susceptibilities of the igneous rocks related to aeromagnetic anomalies in the Chinese continent; the mafic-ultramafic rocks commonly have a high magnetic susceptibility and cause large-scale linear positive magnetic anomalies; the mean value of 14654 mafic-ultramafic rocks is $0.05063 \mathrm{SI}$, equivalent to the magnetization $2 \mathrm{~A} / \mathrm{m}$. Therefore, we think that the strongly magnetized rocks revealed by magnetic anomaly in the basement of Sichuan Basin are more likely mafic-ultramafic.

\section{Geological significance}

Since there is no direct proof to figure out the geological origin of the Sichuan Basin magnetic anomaly, we compared our inverted model with geological maps and found two possible related clues: (1) the range of the magnetic anomaly controls the distribution of the rigid basement beneath Sichuan Basin; (2) the Sichuan Basin magnetic anomaly is mainly surrounded by widespread Neoproterozoic magmatic complexes.

\section{The rigid basement and main faults}

The basement of Sichuan Basin has different properties from the other parts of South China Craton, resembling a stable and rigid block which could resist the deformation of tectonic compressions; the details are as follows: (1) the sedimentary successions from Neoproterozoic to Cenozoic inside the Sichuan Basin are less-deformed and kept as sub-horizontal layers; (2) around the Sichuan Basin, there formed a series of significant faults during the tectonic compressions, e.g., the Longmenshan thrust fault belt in the west of Sichuan Basin and the Dabashan thrust fault belt in the northeast of Sichuan Basin (Zhang et al. 2011); (3) seismic tomography results show that the high-velocity anomaly beneath Sichuan Basin exists down to $300 \mathrm{~km}$, indicating that there is a deep lithospheric root in Sichuan Basin, different from the rest of South China (Huang and Zhao 2006); (4) the mean heat flow of Sichuan Basin is $53 \mathrm{~mW} / \mathrm{m}^{2}$ (Hu et al. 2000; Wang 2001; Xu et al. 2011), lower than that of South China Craton $64 \pm 13.9 \mathrm{~mW} / \mathrm{m}^{2}$ (Hu et al. 2000).

In Fig. 6a, the thrust faults are overlaid on the inversion results displayed by an iso-surface of susceptibility $=0.03$ SI. It shows that the thrust faults in the west and northeast of the Sichuan Basin are spatially related to the range of the magnetic sources. The famous Longmenshan thrust fault belt is in the western margin of the Sichuan Basin, which is still active because of the eastern extrusion of the Songpan-Ganzi Terrane. The trending and location of Longmenshan fault are extremely consistent with those of the magnetic sources beneath Sichuan Basin. Dabashan thrust fault belt is formed by the N-S compression between the North China Craton and Yangtze Terrane on the northeastern margin of Sichuan Basin, including the thrust faults from Dabashan fault to 

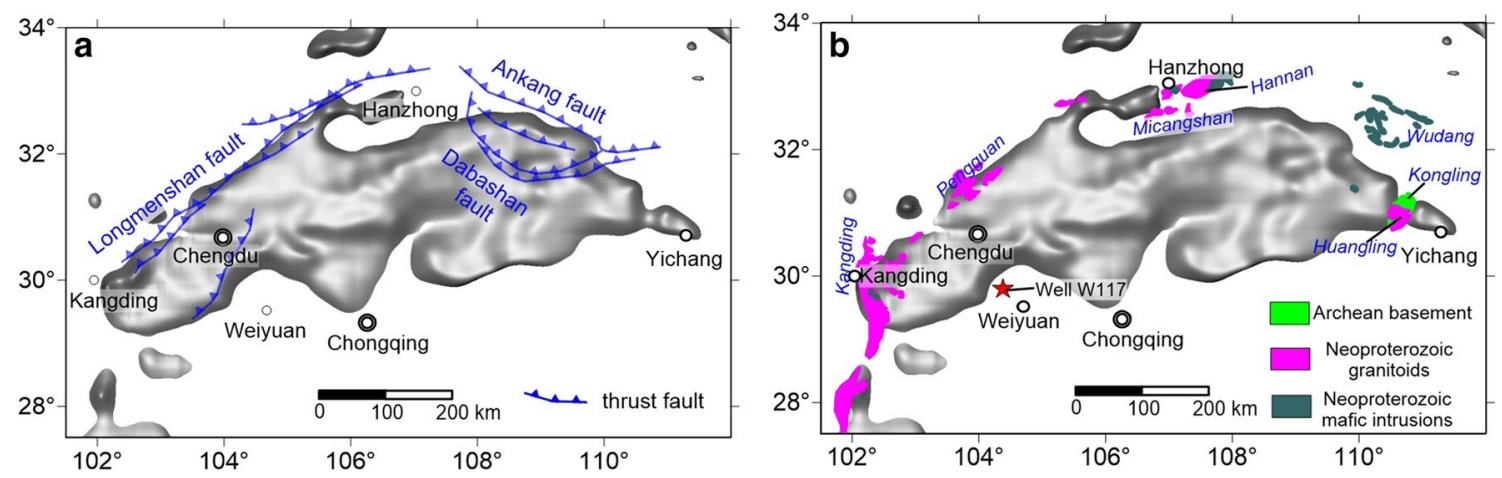

Fig. 6 Comparing our inverted susceptibility model with geological maps. a The main thrust faults around Sichuan Basin. $\mathbf{b}$ The distribution of the Neoproterozoic magmatic rocks. The base map is the inverted model represented by an iso-surface of susceptibility $=0.03 \mathrm{SI}$

Ankang fault. Dabashan fault is the northern boundary of the Sichuan Basin, and the shallow crust from Dabashan fault to Ankang fault has been deformed intensely and fractured, but the high-resolution seismic-reflection profile across the Dabashan fault belt (Dong et al. 2013) shows that the rigid basement beneath the Sichuan Basin extends beyond the Dabashan fault to the Ankang fault. In Fig. 2d, the boundaries of the long-wavelength magnetic anomaly fit well with the faults around Sichuan Basin in the western and northeastern margins, which indicates that the long-wavelength constituents mainly control the spatial distribution of the rigid basement beneath Sichuan Basin.

The distribution of the magnetic anomalies in South China Craton has the similar circumstance. Sichuan Basin magnetic anomaly is the largest and most continuous one; the rest magnetic anomalies in South China Craton are far smaller than Sichuan Basin magnetic anomaly and distributed discretely. This spatial coincidence of the magnetic anomaly and rigid basement in Sichuan Basin indicates that their origins may have genetic connection. Therefore, we think that the geological origin of the Sichuan Basin magnetic anomaly may be related to the last stabilization of the basement; on the other hand, the rigid basement could protect the magnetic anomaly from later tectonic destructions and let the magnetic anomaly preserved well.

\section{Neoproterozoic magmatic rocks}

The basement of Sichuan Basin is stabilized during Precambrian period and the horizontal sedimentary layers began from Neoproterozoic, which indicate that the last reactivation of the basement in Sichuan Basin happened in Neoproterozoic. In the periphery of the basin, the area of outcrops of the Neoproterozoic magmatic rocks is the largest. Figure $6 \mathrm{~b}$ shows the distribution of these Neoproterozoic rocks overlaid on the inversion results. The main bodies include Kangding complex (Du et al. 2007: Lin and Dong 2013), Pengguan complex (Zhang et al. 2008), Hannan-Micangshan complex (Ling et al. 2003, 2006) and Huangling complex (Ji 2014). These Neoproterozoic magmatic complexes are formed during 830-740 Ma, composed of granitoids with minor synchronous mafic intrusions, and their formation is always related to the underplating of the mantle-derived mafic magma (Li et al. 2003a, b, 2008; Zheng et al. 2007; Wang et al. 2009, 2010).

Inside the Sichuan Basin, there is a Well W117 drilling through the 3.6-km-thick sedimentary layers to the basement rocks, and its location is shown in Fig. 6b with a red star. The basement rocks drilled by Well W117 are mainly granites and granodiorites, of which the $\mathrm{Rb}-\mathrm{Sr}$ whole rock isochron age is $740.99 \mathrm{Ma}$ (Luo 1986), and the zircon U-Pb dating of granitoid sample is $794 \pm 11 \mathrm{Ma}(\mathrm{Gu}$ et al. 2014) and $814 \mathrm{Ma}$ (He et al. 2017). So, the basement rocks inside the basin are also formed during Neoproterozoic, the same period as the widespread magmatic complexes around Sichuan Basin. The influence of this Neoproterozoic tectonothermal event is craton scale, not only forming massive intrusions around the basin, but also reactivating the basement inside the basin.

These Neoproterozoic magmatic rocks are distributed in the periphery of the Sichuan Basin magnetic anomaly. Near these outcrops, there are some small branches of the magnetic anomaly. The inversion results show that these small branches are spatially connected to the main magnetic anomaly in Sichuan Basin, indicating the origin of the Sichuan Basin magnetic anomaly may be related to this large-scale Neoproterozoic magmatic event, which played an important role in the evolution of the Sichuan Basin. 


\section{Conclusion}

Sichuan Basin magnetic anomaly reveals massive strongly magnetized rocks in the basement. We applied $3 \mathrm{D}$ inversion to the magnetic data to get the sub-surface susceptibility model. By comparing our inverted model with geological maps, we proposed that the geological origin of the Sichuan Basin magnetic anomaly might be related to the craton-scale Neoproterozoic magmatic event. To further explore the origin of this large magnetic anomaly, more constraints from geophysical detection, dating of the basement rocks and rock magnetism would be needed.

\section{Abbreviation}

RTP: Reduction to the pole.

\section{Acknowledgements}

We thank Prof. Yu Wang and Prof. Zhaohua Luo for their constructive suggestions on our work. We also thank Prof. Stuart A. Gilder and Prof. Rui Gao for their helpful replies to our questions by emails.

\section{Authors' contributions}

JW performed all the analysis and wrote the manuscript. CY analyzed the inversion results and supervised all the work. $Z \mathrm{~L}$ and $\mathrm{YZ}$ wrote the code for 3D inversion. XS, ZZ and WL analyzed and interpreted the inverted model. All authors read and approved the final manuscript.

\section{Funding}

This work is supported by the China Postdoctoral Science Foundation [Grant Number 2019M660731], National High Technology Research and Development Project of China [Grant Number 2014AA06A613] and the National Natural Science Foundation of China [Grant Number 41574132].

\section{Availability of data and materials}

All the magnetic data showed in this article could be downloaded from the websites. The aeromagnetic anomaly data are from EMAG2 (https://www. ngdc.noaa.gov/geomag/emag2.html). The long-wavelength magnetic anomaly data are from the MF7 model (http://geomag.colorado.edu/magne tic-field-model-mf7.html).

\section{Competing interests}

The authors declare that they have no competing interests.

\section{Ethics approval and consent to participate}

Not applicable.

\section{Consent for publication}

Not applicable.

\section{Author details \\ ${ }^{1}$ Institute of Crustal Dynamics, China Earthquake Administration, Beijing, China. ${ }^{2}$ School of Geophysics and Information, China University of Geo- sciences, Beijing, China. ${ }^{3}$ School of Space and Environment, Beihang Univer- sity, Beijing, China. ${ }^{4}$ School of Earth Science and Engineering, Hebei University of Engineering, Handan, China.}

Received: 7 January 2020 Accepted: 19 March 2020

Published online: 30 March 2020

\section{References}

Aitken ARA, Betts PG (2009) Multi-scale integrated structural and aeromagnetic analysis to guide tectonic models: an example from the eastern
Musgrave Province, Central Australia. Tectonophysics 476:418-435. https ://doi.org/10.1016/j.tecto.2009.07.007

An MJ, Shi YL (2007) 3D temperature of crust and lithosphere mantle in Chinese continent. Sci China (D) 37(6):736-745 (in Chinese)

Blakely RJ (1995) Potential theory in gravity and magnetic applications. Cambridge Univ, Cambridge

Brown LL, Webber J, Williams M, Regan S, Seaman S (2014) Magnetism of the lower crust: observations from the Chipman Domain, Athabasca Granulite Terrain, northern Canada. Tectonophysics 624-625:66-74. https://doi. org/10.1016/j.tecto.2013.12.004

Dong S, Gao R, Yin A, Guo T, Zhang Y, Hu J, Li J, Shi W, Li Q (2013) What drove continued continent-continent convergence after ocean closure? Insights from high-resolution seismic-reflection profiling across the Daba Shan in central China. Geology 41:671-674. https://doi.org/10.1130/ G34161.1

Du L, Geng Y, Yang C, Wang X, Zhou X, Ren L, Wang Y, Yang Z (2007) New understanding on Kangding group on western margin of Yangtze block: evidence from geochemistry an chronology. Acta Geol Sin 81(11):15621577 (in Chinese with English abstract)

Ferré EC, Friedman SA, Martín-Hernández F, Feinberg JM, Till JL, lonov DA, Conder JA (2014) Eight good reasons why the uppermost mantle could be magnetic. Tectonophysics 624-625:3-14. https://doi.org/10.1016/j. tecto.2014.01.004

Friedman SA, Feinberg JM, Ferré EC, Demory F, Martín-Hernández F, Conder JA, Rochette P (2014) Craton vs. rift uppermost mantle contributions to magnetic anomalies in the United States interior. Tectonophysics 624-625:15-23. https://doi.org/10.1016/j.tecto.2014.04.023

Fullagar PK, Pears G, Hutton D, Thompson A (2004) 3D gravity and aeromagnetic inversion for MVT lead-zinc exploration at Pillara. Western Australia. Exploration Geophysics 35(2):142-146. https://doi.org/10.1071/eg04142

Gao S, Yang J, Zhou L, Li M, Hu Z, Guo J, Yuan H, Gong H, Xiao G, Wei J (2011) Age and growth of the Archean Kongling terrain, South China, with emphasis on 3.3 GA granitoid gneisses. Am J Sci 311:153-182. https://doi. org/10.2475/02.2011.03

Gao R, Chen C, Wang H, Lu Z, Brown L, Dong S, Feng S, Li W, Wen Z, Li F (2016) SINOPROBE deep reflection profile reveals a Neo-Proterozoic subduction zone beneath Sichuan Basin. Earth Planet Sci Lett 454:86-91. https://doi. org/10.1016/j.epsl.2016.08.030

Gu ZD, Wang ZC (2014) The discovery of Neoproterozoic extensional structures and its significance for gas exploration in the Central Sichuan Block, Sichuan basin, South China. Sci China (D) 57(11):2758-2768

Gu Z, Zhang W, Yuan M (2014) Zircon Shrimp U-Pb dating of basal granite and its geological significance in Weiyuan area of Sichuan Basin. Chinese J Geol 4991:202-213 (in Chinese with English abstract)

Guo L, Gao R, Zhang J, Xiong X (2016) The geosuture between the Yangtze and Cathasia blocks, South China, during Neoproterozoic era revealed from gravity and magnetic data. Chinese J Geol 51(3):682-693 (in Chinese with English abstract)

He DF, Li D, Li CX, Li YQ, Mei QH (2017) Neoproterozoic rifting in the Upper Yangtze continental block: constraints from granites in the Well W117 borehole, South China. Sci Rep 7:1-14. https://doi.org/10.1038/s4159 8-017-12764-y

Hinze WJ, Allen DJ, Fox AJ, Sunwood D, WoelkT, Green AG (1992) Geophysical investigations and crustal structure of the North American Midcontinent Rift system. Tectonophysics 213:17-32. https://doi.org/10.1016/00401951(92)90248-5

Hou Z (1989) Method for calculating and compiling the map of Curie-point surface. Comput Tech Geophys Geochem Explor 11(4):306-311 (in Chinese with English abstract)

Hu S, He L, Wang J (2000) Heat flow in the continental area of China: a new data set. Earth Planet Sci Lett 179:407-419. https://doi.org/10.1016/S0012 $-821 \times(00) 00126-6$

Huang J, Zhao D (2006) High-resolution mantle tomography of China and surrounding regions. J Geophys Res Solid Earth 111:B09305. https://doi. org/10.1029/2005JB004066

Ji W (2014) Late Mesozoic extensional tectonics in South China. University of Orléans, Orléans. (PhD thesis, in Chinese with English abstract)

Li Z (2014) Petromagnetic study on the continental lower crust, northern North China Craton. China University of Geosciences, Wuhan. (PhD thesis, in Chinese with English abstract) 
Li Y, Oldenburg DW (1996) 3-D inversion of magnetic data. Geophysics 61:394-408. https://doi.org/10.1190/1.1443968

Li XH, Li ZX, Ge W, Zhou H, Li W, Liu Y, Wingate MTD (2003a) Neoproterozoic granitoids in South China: crustal melting above a mantle plume at ca. $825 \mathrm{Ma}$ ? Precambrian Res 122:45-83. https://doi.org/10.1016/\$0301 $-9268(02) 00207-3$

Li ZX, Li XH, Kinny PD, Wang J, Zhang S, Zhou H (2003b) Geochronology of Neoproterozoic syn-rift magmatism in the Yangtze Craton, South China and correlations with other continents: evidence for a mantle superplume that broke up Rodinia. Precambrian Res 122:85-109. https://doi. org/10.1016/S0301-9268(02)00208-5

Li ZX, Bogdanova SV, Collins AS, Davidson A, Waele BD, Ernst RE, Fitzsimons ICW, Fuck RA, Gladkochub DP, Jacobs J, Karlstrom KE, Lu S, Natapov LM, Pease V, Pisarevsky SA, Thrane K, Vernikovsky V (2008) Assembly, configuration, and break-up history of Rodinia: a synthesis. Precambrian Res 160:179-210. https://doi.org/10.1016/j.precamres.2007.04.021

Lin GC, Dong JC (2013) Petrogenesis and source characteristics of Neoproterozoic mafic dykes in Kangding-Danba area, western Sichuan. Geol China 40(6):1793-1805 (in Chinese with English abstract)

Ling W, Gao S, Zhang B, Li H, Liu Y, Cheng J (2003) Neoproterozoic tectonic evolution of the northwestern Yangtze craton, South China: implications for amalgamation and break-up of the Rodinia Supercontinent. Precambrian Res 122:111-140. https://doi.org/10.1016/S0301-9268(02)00222-X

Ling WL, Gao S, Cheng JP, Jiang LS, Yuan HL, Hu ZC (2006) Neoproterozoic magmatic events within the Yangtze continental interior and along its northern margin and their tectonic implication: constraint from the ELA-ICPMS U-Pb geochronology of zircons from Huangling and Hannan complexes. Acta Petrologica Sinica 22(2):387-396 (in Chinese with English abstract)

Lü Q, Qi G, Yan J (2013) 3D geologic model of Shizishan ore field constrained by gravity and magnetic interactive modeling: a case history. Geophysics 78(1):B25-B35. https://doi.org/10.1190/GEO2012-0126.1

Luo Z (1986) Is there a paleocontinental nucleus in central Sichuan? J Chengdu College Geol 13(3):65-73 (in Chinese with English abstract)

Luo Z (1998) New recognition of basement in Sichuan Basin. J Chengdu Univ Technol 25(2):191-200 (in Chinese with English abstract)

Mayhew MA, Johnson BD, Wasilewski PJ (1985) A review of problems and progress in studies of satellite magnetic anomalies. J Geophys Res 90:2511-2522. https://doi.org/10.1029/JB090iB03p02511

McEnroe SA, Robinson P, Church N, Purucker M (2018) Magnetism at depth: a view from an ancient continental subduction and collision zone. Geochem Geophys Geosyst 19:1123-1147. https://doi.org/10.1002/2017G C007344

Oldenburg DW, Li Y, Ellis RG (1997) Inversion of geophysical data over a copper gold porphyry deposit: a case history for Mt. Milligan. Geophys 62:1419-1431. https://doi.org/10.1190/1.1444246

Pilkington M, Saltus RW (2009) The Mackenzie River magnetic anomaly, Yukon and Northwest Territories, Canada - evidence for early proterozoic magmatic arc crust at the edge of the North American craton. Tectonophysics 478:78-86. https://doi.org/10.1016/j.tecto.2008.09.006

Regan RD, Marsh BD (1982) The Bangui magnetic anomaly: its geological origin. J Geophys Res 87:1107-1120. https://doi.org/10.1029/JB087iB02p 01107

Roy B, Clowes RM (2000) Seismic and potential-field imaging of the Guichon Creek Batholith, British Columbia, Canada, to delineate structures hosting porphyry copper deposits. Geophysics 65:1418-1434. https://doi. org/10.1190/1.1444831

Silva JBC, Medeiros WE, Barbosa VCF (2001) Potential-field inversion: choosing the appropriate technique to solve a geologic problem. Geophysics 66:511-520. https://doi.org/10.1190/1.1444941
Wang Y (2001) Heat flow pattern and lateral variations of lithosphere strength in China mainland: constraints on active deformation. Phys Earth Planet Inter 126:121-146. https://doi.org/10.1016/S0031-9201(01)00251-5

Wang X, Wang J, Li Q, Yu H (2000) Deep heat flow and geothermal structure in Sichuan Basin of China. In: Proceedings World Geothermal Congress, Kyushu-Tohoku, 28 May-10 June 2000

Wang XC, Li XH, Li WX, Li ZX (2009) Variable involvements of mantle plumes in the genesis of mid-Neoproterozoic basaltic rocks in South China: a review. Gondwana Res 15:381-395. https://doi.org/10.1016/j. gr.2008.08.003

Wang Q, Wyman DA, Li ZX, Bao ZW, Zhao ZH, Wang YX, Jian P, Yang YH, Chen LL (2010) Petrology, geochronology and geochemistry of ca. $780 \mathrm{Ma}$ A-type granites in South China: petrogenesis and implications for crustal growth during the breakup of the supercontinent Rodinia. Precambrian Res 178:185-208. https://doi.org/10.1016/j.precamres.2010.02.004

Wasilewski P, Mayhew MA (1982) Crustal xenolith magnetic properties and long wavelength anomaly source requirements. Geophys Res Lett 9:329-332. https://doi.org/10.1029/GL009i004p00329

Xiong XS, Gao R, Zhang JS, Wang HY, Guo LH (2015) Differences of structure in mid-lower crust between the eastern and western blocks of the Sichuan basin. Chinese J Geophys 58(7):2413-2423 (in Chinese with English abstract)

Xiong S, Yang H, Ding Y, Li Z (2016a) Characteristics of Chinese continent Curie point isotherm. Chin J Geophys 59(10):3604-3617 (in Chinese with English abstract)

Xiong S, Yang H, Ding Y, Li Z, Li W (2016b) Distribution of igneous rocks in China revealed by aeromagnetic data. J Asian Earth Sci 129:231-242. https://doi.org/10.1016/j.jseaes.2016.08.016

Xu M, Zhu CQ, Tian YT, Rao S, Hu SB (2011) Borehole temperature logging and characteristics of subsurface temperature in the Sichuan Basin. Chin J Geophys 54(4):1052-1060 (in Chinese with English abstract)

Zhang X, Hu X, Shen J, Zhao L, Liu M (1995) Relation of apparent magnetization intensity distribution in Sichuan Basin and the earthquake region on its western margin to seismogenic environment. North China Earthquake Sci 13(1):17-22 (in Chinese with English abstract)

Zhang P, Zhou Z, Xu C, Zhang Q (2008) Geochemistry of Pengguan complex in the Longmenshan region, western Sichuan Province, SW China: petrogenesis and tectonic implications. Geotectonica et Metallogenia 32(1):105-116 (in Chinese with English abstract)

Zhang Z, Wang Y, Chen Y, Houseman GA, Tian X, Wang E, Teng J (2009) Crustal structure across Longmenshan fault belt from passive source seismic profiling. Geophys Res Lett 36:1-4. https://doi.org/10.1029/2009GL039580

Zhang YQ, Dong SW, Li JH, Shi W (2011) Mesozoic multi-directional compressional tectonics and formation-reformation of Sichuan basin. Geol China 38(2):234-250 (in Chinese with English abstract)

Zheng YF, Zhang SB (2007) The formation and evolution of the Precambrian continental crust in South China. Chin Sci Bull 52(1):1-10 (in Chienese)

Zheng J, Griffin WL, O'Reilly SY, Zhang M, Pearson N, Pan Y (2006) Widespread Archean basement beneath the Yangtze craton. Geology 34:417-420. https://doi.org/10.1130/G22282.1

Zheng YF, Zhang SB, Zhao ZF, Wu YB, Li X, Li Z, Wu FY (2007) Contrasting zircon $\mathrm{Hf}$ and $\mathrm{O}$ isotopes in the two episodes of Neoproterozoic granitoids in South China: implications for growth and reworking of continental crust. Lithos 96:127-150. https://doi.org/10.1016/j.lithos.2006.10.003

\section{Publisher's Note}

Springer Nature remains neutral with regard to jurisdictional claims in published maps and institutional affiliations. 